\title{
Labor Market And Professional Integration Of Youth In Lebanon: Why Employment Fails?
}

\author{
Eliane Nehme, PhD Assistant Prof.
}

Faculty of Economics and Business Administration, Lebanese University, Achrafieh, Beirut, Lebanon

Georges Nehme, PhD Prof., Dean,

Faculty of Business, Université Antonine, Hadat, Baabda, Lebanon

doi: 10.19044/esj.2016.v12n10p366 URL:http://dx.doi.org/10.19044/esj.2016.v12n10p366

\begin{abstract}
The labor market is not like any other market. It has been the subject of a sufficiently developed theoretical analysis such as the neoclassical model and other complementary or opposed alternative theories. The rigidity of the labor market and the gap between labor supply and labor demand, is due to multiple factors. Companies' limitations are mostly due to their structure, their economic activity, the labor costs, and the absence of structural macroeconomic policies. Moreover, restrictive monetary policy creates pressure on the labor market and increases unemployment. The objective of this research is to prepare, a structural study on labor market and emigration in Lebanon in order to highlight the problems of youth professional integration, the factors of recruitment, the conditions of work, the nature of the activity, and the factors and reasons of emigration. It also aims to propose policies and guidance to overcome the above mentioned difficulties so as to ensure good jobs for young people and prevent emigration.
\end{abstract}

Keywords: Labor market, Human capital, Professional integration, Unemployment, Emigration, Restrictive monetary policy

\section{Introduction}

The labor market is often the first suspect behind the economic problems in general or the growth constraint in particular. The rigidity of the labor market makes it difficult to maintain and create job opportunities. Consequently, the gaps between labor supply and labor demand are born. This is due to multiple factors: the asymmetry of information, the inadequacy of education and training to the needs of the labor market, and the inability 
of the companies to undertake economic growth and generate investments. In fact, companies' limitations are mostly due to their structure, their economic activity, the labor costs, and the absence or deficiencies of structural macroeconomic policies. Furthermore, in the context of macroeconomic policies, the inflation-unemployment relationship also weighs on the labor market. Restrictive monetary policy creates pressure on the labor market and increases unemployment.

The accumulation of quantitative inputs has limited weak effects because of the diminishing returns. Hence, the qualitative criteria remains the most capable of generating sustainable growth on the long term due to technological advances that produce more with the same amount given factors (Solow, 1975) ${ }^{1}$. The human capital is able to create, implement, and continuously develop the technology. Thus, the human capital theory arose through the work of Schultz $(1961)^{2}$ and Becker $(1964)^{3}$ where people are the cornerstone of any technological progress.

The demand for education increased in almost all countries because it improves the productivity and the perceived salary. However, the entrance of a high number of skilled and educated workers to the market creates pressure on labor supply and causes a drop in wages. Despite all these factors, it remains necessary to consider that people are heterogeneous in their wages' expectations, the work they wish to exercise, the choice of their field of education, and the training they want to undertake. Family influences and the financial and intellectual capacities also affect those choices.

Without any doubt, the labor market is affected by quantitative and qualitative factors. It is also affected by the level of education. The labor market is not a market like any other. For this, it has been the subject of a sufficiently developed theoretical analysis such as the neoclassical model and other corresponding/similar or opposed alternative theories. The neoclassical model presents a model where work appears as a commodity. The labor market appears as the place of confrontation between work supply and work demand, generating a high level of employment and real wage equilibrium balance.

According to the neoclassical theory, the market forces can assist in reaching the full employment. Sustainable unemployment does not find its place in this theory. When there is unemployment, it is a sign of a temporary imbalance. The analysis appears to be simple and quantitative by all mean.

\footnotetext{
${ }^{1}$ Solow R, 1957,Technical Change and the Aggregate Production Function, Review Of Economics And Statistics, vol 39

${ }^{2}$ Schultz T.W, 1961, Investment In Human Capital, American Economic Review, vol 51

${ }^{3}$ Becker G, 1964, Human Capital, A Theoretical And Empirical Analysis, With Special Reference To Education, The University Of Chicago Press, Chicago.
} 
These simple and unrealistic assumptions were challenged by the neoclassics themselves, but also by other alternative theories.

Thus imperfections allowed considering the qualitative labor factor. As matter of fact, Workers' qualifications play an important role in wage determination and in the functioning of the labor market. Hence, the theory of human capital and employability (professional insertion) as well as other theories came to overcome the deficiencies of the neoclassical theory.

\section{Material and methods}

The objective of this study is to use and analyze the different theories of the labor market, and consider the importance and specificity of the labor factor in each one. Furthermore, the objective is to analyze the Lebanese labor market, by focusing on the professional insertion of young people. In fact, Lebanon suffers from a high rate of unemployment with an insufficient growth rate pushing young people to emigrate and consequently, Lebanon will lose one of its scarce resources; its human capital. This study analyzes the conditions of access of young people to the labor market, highlighting the factors that help and obstruct their insertion.

Among other factors, the role of a university degree will be analyzed. The role and shortcomings of public intervention in this regard will be highlighted too, aiming to analyze the emigration and its causes at the end of the study.

Is education the only comparative advantage to all the students regardless of their individual characteristics and their social background? What are academic degrees worth in the labor market? Is there a real match between diplomas and jobs?

Finally, this study will attempt to propose strategies on public and private levels, to ensure better integration of young people in the labor market, to create job opportunities, to reduce unemployment, and to allow Lebanon to benefit from its human capital.

The survey was conducted during the summer of 2012 on young Lebanese adults in Lebanon between 18 and 35 years old, from various regions and religions, and it covered the entire Lebanese territory. It took into account various information related to the determinants of the recruitment factors, the working conditions, the nature of the sectorial activity, and the emigration. 


\section{Results and Discussions}

A. The Labor Market: A theoretical framework

The major concern of economists and economic actors is the labor market. The theoretical principles of the labor market are based on the opposition between the neoclassical model and other schools of thought.

\section{The neoclassical labor market ${ }^{4}$, rigidities and imperfections.}

According to the neoclassical model, the functioning of the labor market is based on the analysis of labor supply versus labor demand in a context of perfect competition.

The labor market appears as the place of confrontation of supply and demand of work, generating a high level of employment and real wage equilibrium

balance.

Full employment is not permanent. It is not always reached, but it always tends to improve due to market forces. When the unemployment rate is high, employees are willing to accept lower wages, encouraging companies to hire. That is why, the level of employment increases in order to return to full employment equilibrium. Sustainable unemployment does not find its place in this theory. When there is one, it is a sign of a temporary imbalance.

The neoclassical model is a competitive model where the work appears as a commodity with simple aggregation of individual demands matching offers. This cross matching exercise determines the workload and the real equilibrium wage. The analysis appears simplistic and quantitative by

These simple and unrealistic assumptions were challenged not only by the neo-classics, but also by alternative theories. The hypothesis of atomicity was confronted with the monopolies and the oligopolies. The homogeneity assumption was challenged by human capital differentiated by levels of education and training (Becker Schultz, 1992). Finally, the perfect information hypothesis is confronted with the prospecting cost theory (Stigler, 1961) ${ }^{5}$ and with the signals theory (Spence, 1974) ${ }^{6}$, with the theory of insurance, and finally with the agency theory.

Thus, the inclusion of these imperfections allowed considering qualitative labor inputs and highlighting the qualifications of workers. As said earlier, Workers' qualification plays an important role in wage determination and in the functioning of the labor market. The candidate who is looking for employment is a labor supplier and therefore seeking

\footnotetext{
${ }^{4}$ Blanchard O \& Cohen D, 2007, Macroéconomie ,4ème Edition, Pearson Education.

${ }^{5}$ Stigler G, 1961, The Economics Of Information, Journal Of Political Economy, vol 69.

${ }^{6}$ Spence M, 1974, Market Signaling: Informational Transfer In Hiring And Related Screening Processes, Cambridge Harvard University Press.
} 
information on wages, jobs, and skills (G. Stigler, 1961) ${ }^{7}$. The job seeker refuses the employment offered when the proposed salary is less than the expected minimum wage, hence, the possibility of occurrence of a voluntary unemployment.

On the other hand, the employer is also requesting information. According to the theory of signal (Spence, 1974) ${ }^{8}$, the employer, not knowing the skills of the candidates, will search for all the signals that can help selecting the best candidate, such as degree, marital status, sex, age, mobility, and/or past experience.

Also, as part of the consideration of information asymmetries, the agency theory suggests that the employer must offer wages above the market wage to motivate the agent (the employee) to reveal his qualifications. That said, it would be unwise to propose a wage lower than the market, even in unemployment situation, in order not to discourage good candidates and attract unqualified workers.

\section{The interdependence between goods' market and labor market: The basic Keynesian model}

According to the neoclassical theory, the real wage is characterized by its flexibility while Keynes ${ }^{9}$ model is based on a labor supply depending on descending rigid nominal wages. Workers, according to Keynes, think in nominal terms and are victims of money illusion. They reject a reduction in real wages resulting from lower nominal wage rather than a fall in real wages resulting from a rise in the general price level. So, higher prices do not decrease the level of work load.

Under the Keynesian model, the employer is in a strong position compared to the worker. It's the level of employment that determines the salary and not vice versa. The nominal wage is rigid downward because of periodical collective wage negotiations.

In the goods' market, when the effective demand increases, it increases the level of employment in the same direction. Hence, the effective demand is mainly determined by consumption and investment.

Under the Keynesian model, both goods' markets and labor market depend on the demand. The imbalance originates upstream on the goods' market and affects downstream on the labor market, as the level of business activity affects the level of employment. Then, the policies of stimulus by

\footnotetext{
${ }^{7}$ Stigler G, 1961, The Economics Of Information, Journal Of Political Economy, vol 69.

8 Spence M, 1974, Market Signaling: Informational Transfer In Hiring And Related Screening Processes, Cambridge Harvard University Press.

${ }^{9}$ J.M.Keynes, 1969, Théorie Générale De l’Emploi, De l’Intérêt Et De La Monnaie, Petite Bibliothèque Payot.
} 
demand become important in the fight against unemployment. Expectations of entrepreneurs play a key role in the labor market, since the level of production depends on these expectations and by ricochet the level of employment too.

On the other hand, and according to the neoclassical model, goods' market depends on supply and labor market depends on demand. The imbalance begins in the labor market when the wage is too high and is reflected in the goods market when companies are forced to adapt their profitability based on their costs. Adjustments to policies put in place by the neo-classical theory would be characterized by flexibility in wages.

\section{The employer-employee relationship and other currents views}

According to the Marxist model, society is divided into two classes; the capitalist and the worker. The capitalist abuses the worker. This abuse results in paying only for a part of the executed work. The exploitation rate is measured by the ratio of the unpaid work against the paid work. The capitalist objective is to increase the ratio by increasing the working hours, work intensity and work productivity.

According to the theory of the unions, the power given to workers through unions, grants them the power to interfere in fixing the wages ( $\mathrm{J}$. Hicks $^{10}$ \& J. Dunlop ${ }^{11}$ ). Conflicts of interest arise between workers and managers. Wages are rigid because employees have a greater aversion towards the risk than the employers do. Hence, unions have a crucial role in stabilizing the wages. Because of the unions' interventions, the salary is above its level of acceptance.

The theory of wage bargaining deals with the relation between the unions' actions and the business' decisions. It distinguishes between two types of models: the model of optimal contracts and the model of the right to manage.

The model of optimal contracts, considers that the more the unions are powerful and strong the more the negotiations are in favor of both the employees and the employment (I. McDonald, R. Solow) ${ }^{12}$.

The model of the "right to manage", considers that the more the unions' power is strong the more the employment deteriorates (SJ Nickell,

\footnotetext{
${ }^{10}$ Hicks J.R, 1963, The Theory Of Wages, $2^{\text {nd }}$ Edition, New York, Mac Millan.

${ }^{11}$ Dunlop J.T, 1944, Wage Determination Under Trade Unions, New York, Mac Millan.

${ }^{12}$ MacDonald, I.M, Solow R.M, 1981, Wage Bargaining and Employment, American Economic Review.
} 
P.Kong) ${ }^{13}$ and P. Cahuc ${ }^{14}$. Unemployment, in both models, is the result of the lack of coordination between unions and companies.

The theory of segmentation divides the workforce into two categories (M.J. Piore ${ }^{15}$, B. Bluestone ${ }^{16}$, P. Osterman ${ }^{17}$ ) a primary market, where jobs are stable, well-paid and defended by the unions, and a secondary market, where jobs are risky, poorly paid and poorly defended by the unions. The formulation of employment policy is complicated due to such segmentation of the market. The setting of a minimum wage in the secondary market helps to push the salaries of primary market up in order to maintain the difference in wages between the two sectors. The public sector, just like the private sector, can play a role by acting as an employer and creating jobs for public sector, but this may create a preference in favor of the public sector over the private sector.

According to the French regulationist school, five factors governs the wage ratio (R. Boyer and M. Aglietta ${ }^{18}$ ), 1) external quantitative flexibility (change the number of employees, layoffs, fixed term and temporary employment), 2) internal quantitative flexibility (change the number of working hours, part-time employment), 3) flexibility through outsourcing of activities (sub-contracting), 4) functional flexibility (versatility and turnover of employees), and 5) wages flexibility (adapting the labor cost by modulating the salary).

The distinction between the neoclassical model and other theories shows that the labor market cannot be addressed and analyzed in a basic and simple way. It should be considered holistically, taking into consideration all the imperfections and rigidities to which they are exposed, making it more difficult to formulate the economic policies in terms of employment and growth.

Based on the above and on the Keynesian school of thought according to which the labor market depends on the firms' demand for labor, the importance of the theory of human capital and the human capital investment is increasing. Education is now considered as an investment

\footnotetext{
${ }^{13}$ Nickell S.J, Kong P, December 1992, An Investigation Into the Power Of Insiders In Wage Determination, European Economic Review.

${ }^{14}$ Cahuc P, 1991, Les Négociations Salariales, Economica, Paris.

15 Piore M.J, 1983, Labor Market Segmentation: To What Paradigm Does It Belong? American Economic Review.

${ }^{16}$ Bluestone B, 1970, The Tripartite Economy: Labor Market And The Working Poor. Poverty And Truman Resources Abstracts, vol.5.

${ }^{17}$ Osterman P, 1975, An Empirical Study Of Labor Market Segmentation, Industrial And Labor Relations Review, ILR Review, ILR School, Cornell University.

${ }^{18}$ Aglietta M, 1982, Régulation Et Crises Du Capitalisme, Paris, Calmann-Lévy, 2ème édition.
} 
activity producing human capital. This contributes to better employment, higher wages and increasing productivity. The investment in human capital is able to reduce unemployment and income disparities and to improve the productivity and economic growth.

\section{Lebanese labor market and professional integration: an empirical study}

The asymmetry of information makes the labor market complex and misunderstood by the labor suppliers. Our empirical study in the field of labor market will help to highlight the recruitment factors, the work conditions, the nature of the activity, and the emigration factor.

The survey was conducted during the summer of 2012 in the different Lebanese regions. The selected sample was chosen from the six Mohafazats/districts (Beirut, Mount Lebanon, Bekaa, South Lebanon, North Lebanon, and Nabattieh) with a set of selection criteria, to ensure better diversification and therefore better representation of the sample.

The surveyed population predominantly consists of young people between 18 and 35 years old in accordance with the research questions, which focuses on the professional integration of young people.

\section{The professional integration of youth}

The first step prior to any recruitment is the job hunt. This step is feared by all candidates, due to the uncertainty and lack of knowledge of the labor market. This step may be short timed, medium, or long, depending on several criteria related to the capacity of the job seeker, his field of study, the needs of the labor market, the economic situation....

Moreover, the apprehension of the labor market by potential candidates pushes them to an early search for job even before finishing their first degree. Young people also seem to recognize the importance of professional experience in the job search. Thus, 53.2\% of the surveyed worked prior to earning the first degree, $24.4 \%$ did training, and only $21.2 \%$ did not work before completing their first degree ${ }^{19}$.

For $46 \%$ this work is related to their academic field, showing their interest in their field of study and their impatience to reach the labor market. On the other hand, young people seem to be aware that most of the skills are acquired during employment not before. For $29.2 \%$, the work started before the first degree was outside their field of study; their main objective was to finance their studies and/or provide support to their families. Only $4.8 \%$ consider that the work is more or less related to their field of study ${ }^{20}$.

\footnotetext{
${ }^{19} 1.2 \%$ of selected did not answer this question.

${ }^{20} 20 \%$ of selected did not answer this question.
} 
In general, earning a first degree encourages the candidate to seek employment that is related to their field of study to meet their financial requirements and to ensuring their satisfaction and a good professional career. But is it really the case?

Alternative theories of human capital, without neglecting the value of the degree, show that there are other factors that contribute to the professional integration of young people. So without neglecting the value of the degree, there is another important factor to consider in finding a job, it is the social factor represented by the knowledge and the networks. In fact, when asked about the search method for first job, 34\% of respondents declared that they have found employment through networking relationships, showing that having only a degree is sometimes insufficient. Furthermore, $24 \%$ say that they have found a job after an internship, $19.2 \%$ following a spontaneous application and $8.4 \%$ in response to an advertisement, $14.4 \%$ by other means.

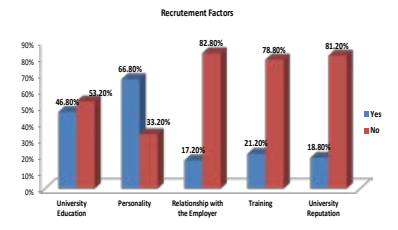

Fig.1. The determinants of recruitment.

Source: Study executed by the authors in 2012-2103.

Also as part of the key elements of recruitment, $53.2 \%$ of respondents believe that the university degree is not decisive for recruitment. For them, the training is more important than the information gained during their university studies. Thus the education-employment relationship seems weak. The universities do not offer courses with real practical experience in the field. Unfortunately, courses are mainly theoretical. One might consider that the schools and the universities do not teach anything useful for the work and that the most talented and smartest people do better than others, because of their intrinsic qualities.

However, one should not overlook the fact that the university through the level of the university degree rather than through training is also a mean of integration to the labor market, since the level of the degree demonstrates 
a certain capacity for its holder, allowing verifying once again the theory of the signal.

In parallel, 66.8\% consider personality as a determinant for recruitment and $18.8 \%$ consider the reputation of the university as a determinant factor too. These survey results (personality and university reputation) justify the filters theory which considers that although education is a criterion for assessing the quality of individuals, we must also consider other criteria such as personality traits, university ranking and reputation...

In addition, $21.2 \%$ consider internships as a determinant, and that most of the skills are gained through work experience, rather than during education. $17.2 \%$ also believe that the relationship with the employer is critical factor.

Thus, as already emphasized in the theoretical part, the lack of education is undoubtedly a handicap in the labor market, but education is not the only selection or productivity criterion. In any case, we can confirm that the financial level of an agent determines its accessibility to the labor market. This level is influenced by the agent's social context. This context consists of the monetary resources or expenses paid by the agent's parents towards his education and his non-monetary resources that are given to him by his parents (personal quality and status of the parents).

From a regional perspective, when talking about the labor market, the analysis on general conditions for conducting business shows that the trend towards the concentration of businesses in urban and peripheral regions persists. However, a larger number of people are settling in the suburbs more and more, due, mainly to the migration of people from the capital to nearby suburbs and to the increase in property prices. Nevertheless, the big bulk of workforce is concentrated in the regions of Beirut and Mount Lebanon. The Capital, Beirut, remains on top of the list. It is important to note that this geographical concentration limits the economic growth and hence, the employment. In fact, when questioned about their workplace, $45.6 \%$ reported working in the Capital while 40.8\% work in Mount Lebanon; this confirms the regional inequality and the deprivation in other regions in terms of job opportunities, pushing the population to leave their home towns and go to Beirut and Mount Lebanon, creating a concentration of a large population in these regions.

The survey shows that $72.8 \%$ of the population is employed by the private sector, $10.4 \%$ by the public sector, and $12.8 \%$ assume a liberal profession $^{21}$. The low share of the liberal professions results from the instability of the country that discourages young people and prevents them

\footnotetext{
${ }^{21} 4 \%$ of the selected population did not answer this question
} 
from taking risks directing them to wage labor. Furthermore, the low share of public sector employees shows the rigidity of public employment.

From a sectorial perspective, the economic activity of the company in which the selected population exercised their first work, is distributed as follows: Services, trade, and finance monopolize the largest number of workers with $42 \%$ of the population, followed by the health sector and social activities with $16.4 \%$, the education $12.8 \%$, the information and communication $9.6 \%$, the construction sector $6 \%$, and others $5.6 \%$. The least advantageous and the least developed sectors in the Lebanese GDP, the industrial the agricultural sectors, attract only $4.8 \%$ and $1.6 \%$ of the population questioned respectively ${ }^{22}$. The drop of agricultural sector is not the result of the modernization of the economy, but it is the effect of the absence of the public intervention to promote this sector; it has never been considered as a priority in the reconstruction plans of the country.

Moreover, the decline of the employment in the industrial sector can't be solely explained by technological innovation and capital-labor substitution. The reasons are in the low competitiveness of Lebanese products and the reliance on the importation. Lebanon is an importer of manufactured goods due to the inability of the local industrial production to meet local or foreign demand. Furthermore, the predominance of small and medium enterprises with their limited financial capacity and the difficulty to find funding, justifies their limited ability to hire.

These findings support the theory of the segmentation that divides the market into two sectors, the primary sector where there are good jobs and employees are well paid as it is the case of the trade and services sectors, and the secondary sector where jobs are bad. Finally, despite the booming in the construction sector, it attracts a very small part of the respondents. The jobs available in this sector require unskilled labor. The low-cost human resources immigration occupies the majority of these vacancies. It is important to note in this respect that a large proportion of foreign workers are illegal.

Regarding the time of work, $72.4 \%$ work on full time basis and $22.8 \%$ on part-time. These figures show the scarcity of part-time job offers, penalizing the students who wish to finance their studies and the women who wish to pursue a professional activity while having a family. The Lebanese labor market is characterized by a lack of internal flexibility invoked by the regulationist school inherited from France and giving the employer the control as demonstrated with Keynesian theory.

Concerning the salaries, $61.2 \%$ receive a monthly salary of less than 1000 USD, $21.2 \%$ get a salary between 1000 and 1500 USD, 7.6\% said

\footnotetext{
$221.2 \%$ of selected did not answer this question.
} 
having a salary between 1500 and 2000 USD, and only 5.2\% obtain a salary greater than or equal to 2000 USD.

As demonstrated by alternative theories of human capital, low wages shows the impact of factors other than the degree on the employment. In fact the demographic factor and the arrival of large numbers of young people into the labor market, not to mention the economic conditions affect the level of wages. This also confirms the employer's power, as alleged by the Keynesian theory.

\section{The employment of holders of a second degree}

As part of the analysis of the professional integration of young people, the correlation between education and employment, and the verification of the applicability of the theory of human capital, the major part of the questionnaire had focused on the possibility of changing job after obtaining a second degree.

The reasons behind changing job after obtaining a second degree are, in general, justified by the dissatisfaction with the first job. Usually after obtaining a graduate degree, the student hopes to find a better job and a better pay. The labor market, according to human capital theory, should value the university degrees. As previously reported in the signal theory and filter theory, the asymmetry of information between the supply and the demand of labor obliges both parties to rely more on signals. The level of education plays the role of filter, assuming that the more educated people are the most efficient they will be. Theoretically, human capital depends, as already reported, on skills, experience, and knowledge.

The theory of human capital finds its justification in the results of the survey, which demonstrated that it is easy to find a new job after a second degree. This highlights the importance of the diploma, but also the professional experience, to help bring together the human capital theory and the alternative theories.

Also within the context of the working conditions, $61 \%$ of the surveyed reported that they do not benefit from any social security. An efficient and generalized social security system is missing in Lebanon. This is due to the budget deficit in general and to the difficulties in financing the National Social Security Fund (NSSF) in particular. From one side, the state cannot provide the support and, on the other side, the funds received by the NSSF are low, due, probably, to the fact that the reported wages are much lower than the real wages or to the booming illegal labor market. This is another factor that pushes young people to emigrate from a country where the costs of health care and of private insurance are very high. 
When asked about the freedom to execute their work, $60 \%$ of the examined population reported not having that freedom. Businesses in Lebanon are mostly small family businesses run by hierarchical power away from decentralization. Decisions are prioritized; young people seem to only occupy executive positions which hinder their professional development and their capacity to take initiatives.

While analyzing the framework of the work conditions of the new job for the employees with a second university degree, it would be interesting to tackle the evolution of the salary and the remuneration. Only 27.2\% received a wage higher than or equal to 1500 USD. These results show the low expectations of the population vis-à-vis the labor market. People seem aware of the difficulties of professional integration in Lebanon and of the gaps between supply and demand of employment. This, once again, demonstrates the validity of the Keynesian theory which shows the growing power of the big business and the low power of the employees.

Moreover, for all salary levels, the majority of the jobs are on full time basis except for the wages higher or equivalent to 4000 USD where only $50 \%$ of the positions are on full time basis. This can be explained by the fact that the persons receiving these high wages, combine several part-time jobs.

Moreover, the wage level increases with experience, showing that the labor market values the professional experience, as well as the level of diplomas, taking into consideration that most skills are acquired during the employment not before.

\begin{tabular}{cccccc}
\hline \multirow{2}{*}{ Current } & \multicolumn{5}{c}{ Years of experience in the current job } \\
\cline { 2 - 5 } salary & $<2$ & {$[2-5[$} & {$[5-10[$} & $\geq 10$ & $\begin{array}{c}\text { No } \\
\text { answer }\end{array}$ \\
\hline$<\$ 1,000$ & $42.50 \%$ & $30.00 \%$ & $12.50 \%$ & $13.75 \%$ & $1.25 \%$ \\
{$[\$ 1,000-$} & $25.93 \%$ & $33.33 \%$ & $18.52 \%$ & $20.99 \%$ & $1.23 \%$ \\
$\$ 1,500[$ & & & & $13.51 \%$ & $0.00 \%$ \\
{$[\$ 1,500-$} & $18.92 \%$ & $37.84 \%$ & $29.73 \%$ & & \\
$\$ 2,000[$ & $26.09 \%$ & $21.74 \%$ & $17.39 \%$ & $34.78 \%$ & $0.00 \%$ \\
{$[\$ 2,000-$} & $25.00 \%$ & $0.00 \%$ & $12.50 \%$ & $62.50 \%$ & $0.00 \%$ \\
$\$ 4,000[$ & $4.76 \%$ & $9.52 \%$ & $9.52 \%$ & $4.76 \%$ & \\
$\geq \$ 4,000$ & & & & \\
\hline No answer & & &
\end{tabular}

Tab.1. The scale of wages based on the years of experience.

Source: Study executed by the authors in 2012-2013. 
These results show that despite the fact that the labor market values the years of experience, the conditions prevailing in the Lebanese labor market remain poor pushing young people to emigrate.

\section{The professional emigration of the young generation}

After reviewing the responses on different working conditions following a first and a second university degree, we noticed that a very large part of the interviewed young people is dissatisfied. This dissatisfaction pushes, as we have already mentioned, them to emigrate. Based on our survey, $48 \%$ of young people want to emigrate to countries where fortune and danger sometimes coexist...

The reasons behind the emigration are mainly the situation in the country followed by the weak labor conditions in Lebanon as showed in the below table.

\begin{tabular}{cc}
\hline Reasons for emigration & Percentage \\
\hline Parents' encouragement & 4.8 \\
Situation in Lebanon & 42.8 \\
Weak labor conditions in Lebanon & 28.0 \\
unemployment & 4.4 \\
Other & 19,6 \\
No answer & 0.4 \\
\hline
\end{tabular}

Tab.2. Reasons for emigration.

Source: Study executed by the authors in 2012-2013.

To better understand the phenomenon of emigration, part of the questionnaire was dedicated to the topic. The answers showed that among those who wish to emigrate, $55 \%$ are men and $45 \%$ women. These results show that men think more about emigration than women. For them, emigration will ensure personal and family security, better working conditions, and a decent wage.

The results of the survey showed that the younger they are, the more motivated they are to emigrate. The youngest are most encouraged taking risks to secure their future; this is why they do not hesitate to consider emigration as a serious and desired alternative option. 


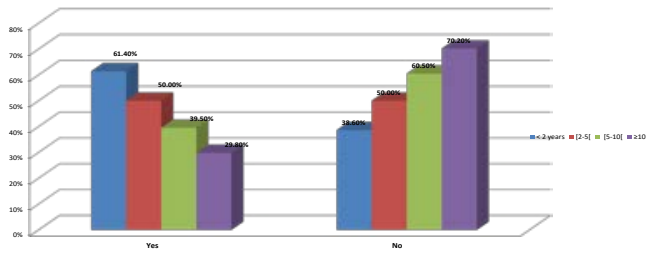

Fig.2. The relationship between years of experience in the current job and the will to emigrate.

Source: Study executed by the authors in 2012-2103.

Based on the survey, fresh graduates with low professional experience are the most motivated to emigrate. In fact, $61.4 \%$ of fresh graduates with less than two years of experience wishes to emigrate compared to only $50 \%$ of the young employees who have between two and five years of experience. The percentage decreases to $39.5 \%$ for young worker having between five and ten years of experience and only $29.8 \%$ for those with ten years of experience or more.

Following the increase in the demand and the supply of education, the number of qualified graduates has increased significantly, causing partially a qualified unemployment and pushing the more qualified workers to emigrate.

No doubt, emigration reduces the human capital of a nation and therefore its well-being.

The main factors that have provoked emigration in Lebanon are, probably, the increasing number of university graduates, the high salaries, the positions requiring skilled human capital available in foreign countries especially in Arab countries (mainly in the Gulf), the high cost of living locally, the low wages offered in Lebanon that reduce the profitability of investment in education, the weak public intervention in the area of job creation, and the political instability that discourages productive investment and promotes the search for stability elsewhere.

Due to the increasing number of higher education institutions, graduated students, and inflation in diplomas, the job market is becoming very competitive and is unable to provide sufficient jobs for a workforce increasingly educated. Increasing wages due to higher levels of education is not substantially significant pushing graduates to seek work abroad. Hence, the demand for education by young people becomes a way to secure a job abroad. 
The labor market in general and the Lebanese private sector in particular pays very poorly for the uneducated workers. In this case, Lebanese private sector often prefers cheap foreign workforce pushing Lebanese youth to accept low wages or forcing them to seek higher education.

For the Lebanese public sector, wages paid to the non-sufficiently educated, are beyond those offered by the private sector. However the public sector recruitment remains difficult and rigid.

Lebanon faces challenges and difficulties to adjust labor supply and labor demand. From the supply side, the population is in continual growth, from 2,100,000 in 1970 to $3,900,000$ in 2001 to 4,100,000 in $2011^{23}$ and $6,180,000$ in $2015^{24}$. This population growth is naturally reflected in the labor market, but with a gap creating tensions towards the increase in labor supply, especially since $68 \%$ of the population is between 15 and 64 years old, therefore in working age ${ }^{25}$. This high percentage can only aggravate tensions on the supply side of the market. Such high percentage shows also that the Lebanese population is an aging population which increases concerns about funding pensions.

Another factor to be considered is the improvement of the educated population. This development shows the growing interest of the population in education despite its rising cost. This is due to the modernization of the Lebanese economy, the reconstruction efforts, and the need for an educated human capital to cope with the innovation and the technological developments. It seems normal to see a higher level of education in countries with low investment and low growth rates.

Since the early century, Lebanese growth continued to score low rates; $1 \%$ in $1999,2000,2001$, negative growth rate in $2006-6.4 \%{ }^{26}, 2.3 \%$ in $2014^{27}$ and only $1 \%$ again in 2015 . This is the result of a very tight monetary policy and high interest rates laid down by the Central Bank. This hinders the financing of the private sector and its cost of production and thus affecting the level of employment. It is important to note that during periods of low growth, young people waiting to find better jobs seek to increase their educational level, which may explain to some extent the increase in the level of education of the Lebanese population.

Finally, the manual and unskilled labor is the last factor explaining the gap between labor supply and demand. The large number of cheap and

\footnotetext{
${ }^{23}$ www.statistiques-mondiales.com/liban.htm

${ }^{24}$ www.statistiques-mondiales.com/liban.htm

${ }^{25}$ Source: Administration Centrale des Statistiques.

${ }^{26}$ Source: Administration Centrale des Statistiques.

${ }^{27}$ www.statistiques-mondiales.com/liban.htm
} 
illegal immigrants from neighboring countries competes with unskilled Lebanese workers and increases the gap between supply and demand of labor for this work category. Thus, in the early 90s, Lebanon absorbed a massive flow of low-skill, low-cost and generally illegal foreign workers. Since the outbreak of the Syrian crisis, this number has increased significantly from 18000 refugees in April 2012 to 1 million in December $2014^{28}$. These workers occupy positions in building construction, housekeeping, and janitors.

On the side of labor demand, small and medium enterprises have a limited hiring capacity. In addition to the small size of the Lebanese companies, the first reason of limited hiring capacity is the weakness of productive investments in Lebanon. Thus, labor demand is constrained by the market size, the size of the Lebanese enterprises, and the geographical and sectorial concentration of the firms. The majority of the Lebanese companies, about $88 \%$, are small family owned businesses, employing less than five persons, lacking funding sources in order to expand, and suffering from the absence of state intervention to increase their competitiveness compared to a competition increasingly hard from foreign products at very low cost which affects employment in Lebanon.

The consequence of these differences between supply and demand for labor is materialized by a high unemployment rate of $21 \%$ in 2014 from which $34 \%$ of young people ${ }^{29}$. These results show that a large share of the unemployed population is often young and fresh graduates. This shows discrepancies between education and qualification, on the one hand, and labor market situation on the other hand.

It is worth mentioning here that there is a lack in the recruitment agencies in Lebanon. The only public body capable of providing services for the unemployed is the National Employment Office. Established with a theoretically broader role, it was reduced to the achievement of several sectorial studies in the field of employment. For vacancies in the public sector, candidates are selected after a competition. For the private sector, recruitment is done through the private human resources offices where political and economic factors appear predominately critical. Cooperation University-labor market remains very limited.

C. The results of the Lebanese Labor market and Market accessibility for fresh graduates

The Keynesian theory was able to demonstrate that the labor market is no longer a simple market obeying the law of supply and demand as

\footnotetext{
${ }^{28}$ http://www.unhcr.org/533c15179.html

Quoting Labor Minister M.Sejaan AZZI 13 January 2016 in: www.lorientlejour.com/article/900523/le-taux-de-chomage-a-21-au-liban.html.
} 
suggested by the neoclassical theory. The labor market is subject to many rigidities arising from the asymmetry of information, the inadequate training to labor market needs, the inability of companies to invest and recruit, and the public interventions deficiencies. The theory of human capital has demonstrated the important role of the qualitative component of the human capital represented by education. Alternative theories of human capital see education but also other factors such as personality, social status, the practice of foreign languages, the academic performance, and the professional experience as signs of the ability of the person to have a high productivity.

Empirical analysis on Lebanon helped to highlight the characteristics of the education system and the labor market in Lebanon providing interaction through the employment of fresh graduates in the labor market.

These Characteristics are:

- $\quad$ Asymmetry of information between job suppliers and job seekers.

- $\quad$ Premature access of students to the labor market before obtaining a first university degree with the aim of financing their studies or gain work experience in the training field.

- $\quad$ Education ensures a better integration for young people and provides them with a better comparative advantage. The degree is however not the only comparative advantage. Other features are taken into account by employers. The diploma shows the internal capacity of the degree holder but does not mean expertise in the field of training.

- $\quad$ Level of the degree and not the field of training is the key element for recruitment in a context in which universities offer only theoretical curriculum.

- Valuation of years of professional experience by the labor market.

- $\quad$ Lack of education and the competition of unskilled, cheap, and often illegal foreign labor are a handicap in the labor market.

- Sectorial inequalities, the inability of the industrial and the agricultural sectors to meet the local and the foreign demand, and the absence of government intervention to ensure the incentives and the development of these two sectors i.e. agriculture and industrial.

- $\quad$ Predominance of small and medium enterprises with limited financial and hiring capacities.

- $\quad$ Concentration of jobs in the capital and its nearby suburbs, promoting the rural exodus in an inadequate infrastructure context.

- $\quad$ Lack of flexibility in employment in terms of working schedule.

- $\quad$ Low wage levels facing the high cost of living, the continual rise in prices and the high costs of educational investment. The unfavorable 
economic conditions and the financial problems of the small Lebanese companies generate low wage levels.

- $\quad$ Strong position of employers compared to the unions' shortcomings and weaknesses disadvantage workers.

- $\quad$ Lack of social coverage for a significant part of the population faced with the high healthcare costs.

- $\quad$ Vicious circle where companies offer low wages and poor conditions pushing young people to have low aspirations or to emigrate.

- $\quad$ Need for skilled workforce but do not know where to find it.

- $\quad$ Population growth is exacerbating tensions on the supply of labor market side and pushes wages downward and provokes youth emigration.

- $\quad$ Locally available jobs have either low yield or low productivity. The non-availability of qualitative jobs for a more skilled workforce favors the emigration of young professional. The size and the structure of the Lebanese economy have always been too narrow in relation to their aspirations.

\section{Conclusion}

The analyses of the education system and the labor market have shown the shortcomings of public sector intervention. This intervention requires the establishment of a comprehensive strategy, which includes the services and goods market, the labor market, the education sector, and the financial sector. Keynesian theory clearly shows that imbalances are starting from the market of goods and services affecting by ricochet the labor market. In fact, public efforts must target goods and services market, by stimulating and encouraging investment in physical capital and allowing a series of job creation. No doubt, this will require the mobilization of financial and human resources.

From a financial resources perspective, the Lebanese government must be able to generate sustainable economic growth, allow greater productivity, and develop export of goods and services capacities. It is also necessary to attract and foster economic growth generating investment sources of employment for young people, rather than relying on Lebanese diaspora income, expatriates working abroad mainly in the Arab Gulf.

The creation of new job opportunities for young people will ensure an adequate return on their educational investment and will give them job opportunities in the local market pushing the youth to stay home. This will allow countries to benefit from its dual capital, physical capital and human capital. These capitals are the source of sustainable economic growth as demonstrated by the Solow model.

Fiscal policy should firstly subsidies the private sector for growthgenerating investments. This requires the development of industrial and 
agricultural sectors, and the development of infrastructure investment projects necessary for the balanced development of all regions, enabling job creation in all regions, not only in the capital and its nearby suburbs. Political stability remains the key milestone of the system, as investments are conditioned to it.

Public spending should also cover areas of public goods such as health, social protection and education. The benefit of these interventions is macroeconomic, since these measures help to improve health, civic responsibility and reduce crime. These measures also help to enhance equity in the society.

The public sector intervention should not only be financial. It is more the establishment of an overall macroeconomic strategy, where the financial component is completed by the implementation of measures and regulations that complement the financial aspect.

Regulations should also promote the industrial and the agricultural sectors and enable the banking sector to be at their service and promote their development similar to what has been done in South-East Asia where finance was in the service of the industry and not the other way around.

Regulations should also affect the educational sector. The government must guarantee the quality of its educational sector, especially after the dramatic growth in the number of private institutions of higher education. The government, through the Ministry of Education and Higher Education, must reduce the licensure for opening of new establishments and submit existing institutions to strict quality assurance criteria.

The regulations should check illegal work and declared salaries paid by enterprises.

It would also be necessary to highlight the role of the monetary policy. Lebanon adopted a restrictive monetary policy of fixed exchange rate against the dollar, allowing the stability of the Lebanese Pound and promoting the attraction of foreign capital and the maintenance of a surplus in the payment balance despite the growing deficit of the trade balance. The interest rates on the Lebanese pound are therefore high. This restrictive monetary policy that aimed for external stability is not without consequences on the internal objectives and more precisely on the decrease in the investment level and the increase in the unemployment rates. However, the flexibility of this policy remains conditional to the political stability which affects the economic stability.

Finally, it would be necessary to ensure greater cooperation between the universities and the labor market through the creation of specialized career offices which centralize offers and job applications.

All these measures will contribute to the decrease in the emigration rate and would allow Lebanon to enjoy the best of its human capital. 
Acknowledgment: The research has been funded with support from the Lebanese University

\section{References:}

Aglietta, M. (1982). Régulation Et Crises Du Capitalisme. Paris, CalmannLévy.

Becker, G. (1964). Human Capital, A Theoretical And Empirical Analysis, With Special Reference To Education. Chicago, The University Of Chicago Press.

Blanchard, O. \& Cohen, D. (2007). Macroéconomie. Harlow, Pearson Education.

Bluestone. B, (1970). The Tripartite Economy: Labor Market And The Working Poor. Poverty And Truman Resources Abstracts. vol.5.

Cahuc, P. (1991). Les Négociations Salariales. Paris, Economica.

Dunlop, J.T. (1944) Wage Determination Under Trade Unions. New York, Mac Millan.

Hicks. J.R. (1963). The Theory Of Wage. New York, Mac Millan.

Keynes, J.M. (1969). Théorie Générale De l'Emploi, De l'Intérêt Et De La Monnaie. Paris, Petite Bibliothèque Payot.

MacDonald. I.M. \& Solow, R.M. (1981). Wage Bargaining and Employment. American Economic Review.

Nickell. S.J. \& Kong. P. (1992, December). An Investigation Into the Power Of Insiders In Wage Determination. European Economic Review.

Osterman. P. (1975). An Empirical Study Of Labor Market Segmentation. Industrial And Labor Relations Review.

Piore. M.J. (1983) Labor Market Segmentation: To What Paradigm Does It Belong? American Economic Review.

Schultz, T.W. (1961). Investment In Human Capital. American Economic Review, 51.

Solow, R. (1957). Technical Change and the Aggregate Production Function. Review Of Economics And Statistics, 39.

Spence, M. (1974). Market Signaling: Informational Transfer In Hiring And Related Screening Processes. Cambridge, Harvard University Press.

Stigler, G. (1961). The Economics Of Information. Journal Of Political Economy, 69. 